\title{
Pengembangan Media Game Edukasi “Kirun Mission” Materi Keragaman Budaya Indonesia dengan Penguatan Karakter Jujur untuk Siswa Kelas IV Sekolah Dasar
}

\author{
Elcinta Fridaynia Yunna Nabela, Sri Murdiyah*, Putri Mahanani \\ Universitas Negeri Malang, Jl. Semarang No. 5 Malang, Jawa Timur, Indonesia \\ *Penulis korespondensi, Surel: murdiyahsri@gmail.com
}

Paper received: 7-6-2021; revised: 21-6-2021; accepted: 28-6-2021

\begin{abstract}
Abstrak
Pemanfaatan sumber belajar saat proses pembelajaran dapat dioptimalkan dengan menggunakan media. Namun, pada kenyataan masih terdapat kendala dalam penyampaian materi muatan IPS di kelas IV SDN Sentul 3 Kota Blitar dan SDN Karangsari 2 Blitar. Permasalahan yang sama antara kedua SD tersebut yaitu (1) cakupan materi keragaman budaya yang luas dan tidak adanya media pendukung (2) Pada saat diberikan tugas banyak siswa yang mengumpulkan jawaban yang sama dengan temannya. Melihat hal tersebut perlu dikembangkan salah satu media pembelajaran interaktif serta mampu menumbuhkan karakter pada siswa. Media pembelajaran dikemas berupa game edukasi agar siswa dapat memahami materi tersebut dengan menarik dan dapat menggunakan media tersebut dimanapun.Tujuan penelitian pengembangan ini untuk menghasilkan sebuah media game edukasi "Kirun Mission" berbasis karakter jujur keragaman budaya Indonesia di kelas IV SD yang valid menurut ahli materi dan ahli media, praktis digunakan oleh guru serta praktis dan menarik bagi siswa kelas IV SD.
\end{abstract}

Kata kunci: media; karakter jujur; keragaman budaya; SD

\section{Pendahuluan}

Pendidikan merupakan usaha yang dilaksanakan untuk mengembangkan potensi siswa saat proses pembelajaran berlangsung. Pada proses pembelajaran memang tidak dapat berjalan dengan efektif tanpa adanya sumber-sumber belajar. Agar pembelajaran dapat berjalan sesuai dengan proses yang diharapkan, maka pemanfaatan sumber belajar dapat dioptimalkan salah satunya yaitu dengan menggunakan media pembelajaran. Menurut Musfiqon (2012) mengungkapkan bahwa media pembelajaran berperan penting dalam menjelaskan materi agar pembelajaran menjadi lebih efektif dan efisien sehingga materi pembelajaran lebih cepat diterima siswa secara utuh dan mampu menarik minat siswa untuk belajar lebih lanjut.

Media pembelajaran sebagai alat bantu pada proses pembelajaran memiliki hubungan yang sangat erat dengan setiap muatan pelajaran. Salah satu muatan pelajaran tersebut yaitu Ilmu Pengetahuan Sosial (IPS). Menurut Gunawan dalam Rojuli (2016) pendidikan IPS di SD merupakan bidang studi yang mempelajari manusia dalam semua aspek kehidupan dan interaksinya dalam masyarakat. Pada pembelajaran IPS, guru hendaknya mampu menjadi pengarah siswa agar dapat berpikir kritis, berperan aktif, dan menjadikan suatu pembelajaran berjalan dengan menyenangkan. Hal tersebut sesuai dengan pendapat Mahanani (2013) guru hendaknya menyiapkan berbagai media dan sumber belajar yang dibutuhkan dalam proses pembelajaran yang disesuaikan dengan lingkungan keberadaan siswa.Namun, pada kenyataan di lapangan masih terdapat kendala dalam penyampaian materi IPS kepada siswa. 
Berdasarkan hasil wawancara yang telah dilaksanakan dengan guru di kelas IV SDN Sentul 3 Kota Blitar yaitu Ibu Maratin S. Pd.SD pada Rabu, 13 Januari 2021 dan SDN Karangsari 2 Kota Blitar yaitu Ibu Sukaningtyas, S.Pd.SD pada Selasa, 16 Februari 2021. Berdasarkan informasi antara kedua SD tersebut permasalahan yang sama yaitu cakupan materi keragaman budaya yang luas dan tidak adanya media pendukung dalam proses pembelajaran juga menjadikan siswa malas untuk mempelajari dan memahami materi dengan cermat. Materi yang tidak didukung dengan gambar yang menarik karena berupa gambar yang hitam putih, serta tidak adanya kelengkapan gambar sesuai dengan 34 provinsi di Indonesia menjadikan siswa bosan dan tidak tertarik mempelajari keragaman budaya. Sehingga pada saat diberikan tugas, masih banyak siswa yang mengumpulkan jawaban yang sama dengan temannya terlihat dari banyak salah dan benar saat pengumpulan tugasnya, karena siswa merasa kurang percaya dengan hasil kemampuannya sendiri. Hal ini menunjukkan bahwa siswa masih menyontek hasil pekerjaan temannya sehingga penerapan karakter jujur pada suatu muatan pelajaran masih belum berjalan secara optimal. Padahal, pendidikan karakter sudah seharusnya dapat diterapkan dalam proses belajar mengajar pada semua muatan pelajaran (Yuniawatika \& Nuraini, 2017).

Berdasarkan beberapa permasalahan di atas, secara umum dapat menjadi dasar perlunya dikembangkan salah satu media pembelajaran interaktif yang menarik dan menyenangkan serta mampu menumbuhkan karakter pada siswa. Media belajar yang dikembangkan bersifat online sehingga pengguna dapat mengakses kapanpun hampir diseluruh dunia. Menurut Chabib dkk (2017) pendekatan yang dapat digunakan guru dalam mengajar di dalam kelas salah satunya merupakan pendekatan bermain sambil belajar (playing by learning). Hal ini didukung dengan penelitian terdahulu milik Arif (2016) berupa pengembangan game edukasi interaktif pada mata pelajaran komposisi foto digital kelas XI di SMK Negeri 1 Surabaya, dimana dari pengembangan ini dihasilkan sebuah media yang menunjukkan hasil belajar siswa yang memuaskan dan media tersebut layak untuk digunakan. Melihat dari hasil penelitian tersebut, menandakan bahwa game edukasi perlu dikembangkan sebagai media pembelajaran yang interaktif dapat memudahkan siswa dalam belajar sehingga memengaruhi hasil belajarnya.

Namun, jika dilihat dari kondisi saat ini dimana sedang marak terjadi kasus pandemi Covid-19, maka kegiatan belajar mengajar pun akhirnya dibuat dengan sistem belajar dari rumah. Media pembelajaran yang dikemas dalam bentuk game edukasi terutama pada kondisi pandemi Covid-19 ini yang dapat menunjang proses pembelajaran. Sehingga, penggunaan media game edukasi ini merupakan salah satu solusi yang tepat untuk digunakan dalam pembelajaran karena mampu memanfaatkan teknologi yang tersedia serta tetap menjadikan siswa dapat belajar dari rumah.

Game edukasi yang dikembangkan dalam penelitian ini yaitu berjudul "Pengembangan Media Game Edukasi “Kirun Mission" Materi Keragaman Budaya Indonesia dengan Penguatan Karakter Jujur untuk Siswa Kelas IV Sekolah Dasar". Tujuan penelitian dan pengembangan menghasilkan produk berupa media game edukasi "Kirun Mission" materi Keragaman Budaya Indonesia dengan penguatan karakter jujur yang valid menurut ahli materi dan ahli media, praktis digunakan oleh guru serta menarik dan praktis bagi siswa kelas IV SD. 


\section{Metode}

Rancangan pengembangan ini mengacu pada model pengembangan ADDIE menggunakan 5 tahapan proses yang dilakukan yaitu: (1) Analysis (analisis); Penilaian kebutuhan dilaksanakan dengan cara menemukan akar permasalahan diketahui melalui kegiatan wawancara bersama guru muatan pelajaran IPS kelas IV SDN Sentul 3 Kota Blitar pada 13 Januari 2021 dan SDN Karangsari 2 Kota Blitar pada 16 Februari 2021 dengan melakukan chatting melalui via whatsApp. (2) Design (Rancangan); Mengembangkan desain pengembangan media. (a) Menentukan konsep dan membuat flowchart game, (b) Mengembangkan materi untuk game, (c) Membuat desain untuk game (d) Mencari backsound game, (e) Membuat dubbing dalam game, (f) Membuat rancangan game, (g) Membuat link web, (h) Membuat buku petunjuk penggunaan game. (3) Development (Pegembangan); Pengembangan instrumen penilaian menjadi 10 butir soal evaluasi terkait pengetahuan siswa mengenai materi keragaman budaya Indonesia. (4) Implementation (Penerapan); Instrumen penilaian yang dikembangkan meliputi instrumen validasi materi dan media serta angket respon guru dan siswa. (5) Evaluation (Evaluasi); Berisi pernyataan mengenai hasil penelitian pengembangan yang telah dilaksanakan. Apabila dalam melakukan uji coba keseluruhan sudah tidak terdapat kesalahan dan kendala serta hasil angket yang disebarkan kepada siswa sudah menunjukkan kepraktisan dan kemenarikan game edukasi maka media layak digunakan.

Sumber data dalam penelitian ini bersumber dari berbagai pihak, antara lain yaitu sebagai berikut. (a) Ibu Sukaningtyas, S.Pd selaku guru muatan pelajaran IPS kelas IV di SDN Karangsari 2 Kota Blitar sebagai narasumber. (b) Ibu Maratin, S.Pd selaku guru muatan pelajaran IPS kelas IV di SDN Sentul 3 Kota Blitar sebagai narasumber dan penilai kepraktisan media game edukasi. (c) Validasi Ahli ; (1) Ahli materi selaku dosen Program Studi Pendidikan Guru Sekolah Dasar Universitas Negeri Malang yaitu Prof. Dr. H. M. Zainuddin, M.Pd. (2) Ahli media selaku dosen Program Studi Teknologi Pendidikan Universitas Negeri Malang yaitu Drs. Suhel Madyono, SPd., M.Pd. (d) Uji Coba Produk; (1) Uji Coba Kelompok Kecil: sumber data yaitu siswa kelas IV SDN Sentul 3 Kota Blitar yang berjumlah 5 anak yang dilakukan di rumah peneliti. (2) Uji Coba Kelompok Besar: sumber data yaitu siswa kelas IV SDN Sentul 3 Kota Blitar yang berjumlah 15 siswa dilakukan secara online dikarenakan pembelajaran sekolah dilakukan secara daring.

Pada penelitian ini, Pengembangan materi IPS yang dibahas disesuaikan dengan buku tema 7 Indahnya Keragaman di Negeriku subtema 2 "Indahnya Keragaman Budaya Negeriku" pada pembelajaran 3 dan 4 dimana materi Keragaman Budaya membahas mengenai rumah adat dan pakaian adat. Adapun keragaman rumah adat di Indonesia yang merujuk dari (Putri, 2020). Sedangkan Keberagaman pakaian adat di Indonesia menurut (Kristiani \& Bemoe, 2016).

Penelitian ini menggunakan instrumen pengumpulan data wawancara dilakukan untuk memperoleh informasi dari guru kelas IV SDN Sentul 3 Kota Blitar pada tanggal 13 Januari 2021 dan SDN Karangsari 2 Kota Blitar pada tanggal 16 Februari 2021. Serta angket yang berisi lembar validasi ahli materi dan ahli media angket ini digunakan untuk mengetahui kevalidan produk game edukasi Kirun Mission. Angket validasi ahli dalam lembar validasi ahli materi dan ahli media menggunakan skala likert. Menurut Setyosari (2015) pengukuran dengan skala likert menggunakan rentang nilai 1-4 dengan kriteria (1) sangat tidak baik, (2) tidak baik, (3) baik, (4) sangat baik. Sedangkan angket respon siswa dalam lembar uji kepraktisan, kemenarikan dan kejujuran yaitu menggunakan skala guttman. Menurut 
Sugiyono (2019) skala guttman merupakan skala yang hasil jawabannya tegas berupa "yatidak".

Analisis data pada tahap ini meliputi teknik analisis data kualitatif dan data kuantitatif. Teknik analisis data kualitatif pada penelitian ini berupa hasil wawancara, kritik, dan saran dari ahli materi, ahli media, serta pengguna yang dapat dianalisis secara deskriptif. Teknik analisis data kuantitatif pada penelitian tersebut didapatkan dari nilai angket validasi ahli materi, ahli media, hasil uji kepraktisan untuk pengguna serta kepraktisan dan kemenarikan untuk siswa.

Analisis kelayakan media didapat dari 2 validator yang terdiri dari: ahli media dan ahli materi. Data yang diperoleh berupa data kuantitatif dan kualitatif. Data kuantitatif berupa hasil validasi dengan teknik perhitungan persentase kelayakan media. Data kualitatif diperoleh dari saran dan komentar sebagai bahan perbaikan produk oleh peneliti. Fungsi perhitungan untuk mengetahui peringkat nilai akhir setiap butir yang bersangkutan. Perhitungan persentase kelayakan media menggunakan metode yang dicontohkan oleh Akbar (2013).

$V a=\frac{T s e}{T s h} \times 100 \%$

Analisis kepraktisan dilakukan dengan cara menghitung rata-rata skor untuk menentukan kepraktisan dari respon praktisi guru, serta kemenarikan, kepraktisan dan kejujuran dari respon siswa cara perhitungannya menggunakan rumus (Arikunto S, 2010) sebagai berikut:

$P=\frac{\sum x}{N} \times 100 \%$

\section{Hasil dan Pembahasan}

\subsection{Hasil}

Setelah dilaksanakan penelitian pengembangan sesuai prosedur penelitian pengembangan yang menggunakan model penelitian Addie didapatkan hasil validasi dari para ahli, hasil nilai kepraktisan dari guru serta nilai kepraktisan dan kemenarikan siswa kelas IV SD. Data hasil penilaian tersebut dipaparkan dalam tabel sebagai berikut.

Tabel 1. Data Hasil Penilaian Produk Game Edukasi Kirun Mission

\begin{tabular}{llcc}
\hline No. & \multicolumn{1}{c}{ Validator } & Persentase & Kategori \\
\hline 1. & Ahli Materi & $95 \%$ & Sangat valid \\
2. & Ahli Media & $100 \%$ & Sangat valid \\
3. & Kepraktisan Pengguna (Guru) & $100 \%$ & Sangat praktis \\
4. & Siswa Uji Coba Kelompok Kecil & $100 \%$ & Sangat praktis dan menarik \\
5. & Siswa Uji Coba Kelompok Besar & $99,5 \%$ & Sangat praktis dan menarik \\
\hline
\end{tabular}

Menurut tabel 1, telah diperoleh hasil validasi game edukasi dari ahli materi sebesar 95\% dan hasil validasi ahli media sebesar 100\% dimana keduanya termasuk ke dalam kategori sangat valid. Selain itu, diperoleh hasil penilaian dari uji kepraktisan kepada guru sebagai pengguna dengan persentase sebesar 100\% dengan kategori sangat praktis. Pada kegiatan uji coba kelompok kecil diperoleh nilai kepraktisan dan kemenarikan sebesar $100 \%$ dan pada 
kegiatan uji coba kelompok besar juga diperoleh nilai kepraktisan dan kemenarikan sebesar 99,5\%, dimana keduanya termasuk ke dalam kategori sangat praktis dan menarik. Hasil data secara keseluruhan tersebut menunjukkan bahwa produk game edukasi Kirun Mission dapat dinyatakan layak untuk digunakan sebagai salah satu media pembelajaran pada materi keragaman budaya Indonesia (rumah adat dan pakaian adat) di Tema 7 "Indahnya Keragaman di Negeriku", Subtema 2 "Indahnya Keragaman Budaya Negeriku” muatan pelajaran IPS kelas IV SD yang telah valid menurut ahli materi, ahli media, praktis untuk digunakan oleh guru dan praktis serta menarik digunakan siswa kelas IV SD.

\subsection{Pembahasan}

Pengembangan media game edukasi Kirun Mission pada materi keragaman budaya Indonesia ini telah dilakukan validasi ahli materi dan ahli media, kepraktisan pengguna, serta kepraktisan dan kemenarikan oleh siswa. Penjelasan mengenai hasil validasi dipaparkan sebagai berikut.

Validasi materi mengenai hasil pengembangan media game edukasi Kirun Mission dilakukan oleh ahli materi. Ahli materi ialah dosen Pendidikan Guru Sekolah Dasar Fakultas Ilmu Pendidikan Universitas Negeri Malang yaitu Prof. Dr. H. M. Zainuddin, M.Pd yang dilaksanakan pada tanggal 16 April 2021. Angket validasi materi terdiri dari 5 aspek penilaian antara lain yaitu isi materi, cakupan materi, kebahasaan/komunikasi, teknik penyajian materi, dan ketepatan penulisan dan kalimat. Media game edukasi dikemas menjadi bahasa yang sesuai dengan kehidupan sehari-hari, santun dan dapat dipahami serta penyampaiannya dibuat komunikatif agar informasi dalam media game edukasi Kirun Mission dapat dengan mudah diterima oleh siswa. Hal ini sesuai dengan salah satu fungsi media pembelajaran menurut Sanjaya dalam Cahyo dkk (2021) fungsi komunikatif saat menyampaikan materi. Berdasarkan penghitungan nilai rata-rata validasi materi, produk media game edukasi Kirun Mission mendapat hasil nilai kevalidan sebesar 95\% yang jika diinterpretasikan menggunakan tabel kriteria tingkat kelayakan mendapatkan hasil yang sangat valid dengan penjelasan dapat digunakan tanpa revisi.

Produk game edukasi Kirun Mission ini telah dilakukan validasi oleh ahli media pada tanggal 15 April 2021 secara langsung. Aspek penilaian validasi media antara lain meliputi perangkat lunak/aplikasi, kebahasaan/komunikasi, teknik penyajian materi, tampilan, dan tampilan menyeluruh. Berdasarkan penghitungan nilai rata-rata validasi media, produk game edukasi Kirun Mission mendapat hasil nilai kevalidan media sebesar 95\% yang jika diinterpretasikan menggunakan tabel kriteria tingkat kelayakan mendapatkan hasil yang sangat valid dengan penjelasan dapat digunakan tanpa revisi. Hasil validasi ini dapat dikatakan sudah baik karena pada penelitian sebelumnya yaitu milik Arif \& Sumbawati (2016) yang juga mengembangkan sebuah game edukasi interaktif pada mata pelajaran lain untuk digunakan di kelas XI SMK hanya mendapatkan nilai validasi media sebesar 68,3\%.

Uji kepraktisan media game edukasi Kirun Mission telah dilaksanakan secara langsung oleh guru kelas IV SDN Sentul 3 Kota Blitar yaitu Ibu Maratin Nafi'ah, S.Pd.SD pada tanggal 16 April 2021. Aspek penilaian kepraktisan terdiri atas 5 aspek antara lain isi materi, cakupan materi, kebahasaan/komunikasi, teknik penyajian dan ketepatan penulisan dan kalimat. Berdasarkan penghitungan nilai rata-rata kepraktisan oleh guru, produk game edukasi Kirun Mission mendapat hasil nilai kepraktisan sebesar 100\% yang jika diinterpretasikan 
menggunakan tabel kriteria tingkat kepraktisan yang merujuk dari Akbar dalam Kumalasani (2018) termasuk ke dalam interval 75,01\% - 100,00\% dengan kategori sangat praktis sehingga dinyatakan dapat digunakan tanpa revisi.

Kegiatan uji coba kelompok kecil dilaksanakan untuk mengetahui kekurangan media game edukasi Kirun Mission dan permasalahan yang ditemui pada kegiatan uji coba ini. Sehingga, setelah kegiatan uji coba kelompok kecil, dapat dilakukan perbaikan media game edukasi Kirun Mission. Kegiatan ini dilaksanakan pada tanggal 03 Mei 2021 dengan subjek penelitian berjumlah 5 siswa dengan tingkat kemampuan yang berbeda-beda. Untuk mengetahui tingkat kepraktisan dan kemenarikan media game edukasi Kirun Mission, digunakan angket respon siswa terhadap produk yang terdiri dari 10 pertanyaan dengan pilihan jawaban "ya dan tidak". Berdasarkan penyebaran angket yang telah diberikan kepada siswa dan dilakukan analisis, didapatkan nilai rata-rata kepraktisan media game edukasi Kirun Mission dengan persentase sebesar 100\%. Persentase tersebut jika dilihat berdasarkan tabel tingkat kepraktisan yang merujuk pada Akbar dalam Kumalasani (2018), maka media game edukasi Kirun Mission dinyatakan sangat praktis dan dapat digunakan tanpa revisi.

Proses pembelajaran dengan menggunakan media game edukasi Kirun Mission terintegrasi dengan karakter jujur. Penilaian karakter sendiri terdiri dari 4 indikator pencapaian. Berdasarkan hasil penilaian karakter yang telah dilaksanakan, menunjukkan bahwa siswa sudah terintegrasi karakter jujur. Pendidikan karakter yang diterapkan dalam pendidikan, salah satunya yaitu karakter jujur. Secara umum, kata jujur merupakan apa yang dikatakan sesuai dengan hati nuraninya apa yang dikatakannya sesuai dengan kenyataan yang ada. Menurut Ridwan \& Mudiono (2017) keadaan dimana jika manusia tidak jujur maka tidak mempunyai nilai kebaikan dihadapan orang lain. Oleh karena itu, penting untuk mengembangkan karakter jujur pada diri siswa supaya ia dapat dipercaya orang lain. Pembelajaran berbasis karakter jujur bertujuan untuk menjadikan siswa dapat melakukan aktivitas secara jujur.

Setelah melaksanakan kegiatan uji coba kelompok kecil, maka dilanjutkan dengan melaksanakan kegiatan uji coba kelompok besar. Kegiatan ini dilaksanakan untuk mengetahui tingkat kepraktisan dan kemenarikan media game edukasi Kirun Mission. Kegiatan uji coba kelompok besar ini telah dilaksanakan pada tanggal 04 Mei 2021 secara daring. Aspek penilaian media game edukasi Kirun Mission ini meliputi 10 pertanyaan yang diberikan kepada siswa melalui google form. Berdasarkan hasil rekapitulasi angket respon siswa terhadap produk pada saat uji coba kelompok besar, didapatkan hasil nilai rata-rata kepraktisan sebesar 99,5\%. Pada uji coba kelompok besar mengalami penurunan pada petunjuk penggunaan media mengalami penurunan dikarenakan salah satu siswa memilih tidak pada angket respon siswa yang disebarkan melalui google form. Persentase tersebut jika disesuaikan berdasarkan tabel tingkat kepraktisan dan kemenarikan yang merujuk pada Akbar dalam Kumalasani (2018), maka media game edukasi Kirun Mission ini dapat dinyatakan sangat praktis dan dapat digunakan tanpa revisi.

Proses pembelajaran dengan menggunakan media game edukasi Kirun Mission terintegrasi dengan karakter jujur. Penilaian karakter sendiri terdiri dari 4 indikator pencapaian. Berdasarkan hasil penilaian karakter yang telah dilaksanakan, menunjukkan bahwa siswa sudah terintegrasi karakter jujur. Hal ini sejalan dengan pendapat dari Fadillah \& Khorida dalam Sari (2019), yang mengungkapkan bahwa seseorang dengan jiwa kejujuran 
yang tinggi maka siswa dapat menjalani kehidupannya dengan baik. Sehingga dapat disimpulkan bahwa dengan menggunakan media game edukasi Kirun Mission pada pembelajaran IPS di kelas IV SD ini diharapkan dalam diri siswa mampu terbentuk karakter jujur yang mampu menjadikan siswa selalu optimis, dan percaya terhadap diri sendiri.

Berdasarkan tahapan dari hasil uji coba kelompok kecil dan besar di atas, maka dapat disimpulkan bahwa media game edukasi Kirun Mission dinyatakan sangat praktis, menarik dan layak untuk digunakan sebagai salah satu media pembelajaran pada materi Keragaman Budaya Indonesia (rumah adat dan pakaian adat) dengan penguatan karakter jujur untuk siswa kelas IV SD.

\section{Simpulan}

Berdasarkan hasil analisis data, dapat disimpulkan bahwa produk game edukasi Kirun Mission materi keragaman budaya Indonesia dengan penguatan karakter jujur untuk siswa kelas IV SD yang telah dikembangkan termasuk dalam kategori sangat valid dan layak untuk digunakan. Adapun produk game edukasi Kirun Mission mendapatkan rata-rata nilai validasi menurut ahli materi sebesar 95\%, dan menurut ahli media sebesar 100\%. Meskipun mendapatkan nilai validasi yang baik, produk game edukasi Kirun Mission ini masih memiliki kekurangan sehingga perlu untuk dilakukan perbaikan. Adapun saran dan masukan dari para ahli antara lain yaitu, perlu mengurutkan materi yang memiliki prasyarat. Media game edukasi Kirun Mission juga telah diuji kepraktisannya oleh pengguna yaitu guru kelas IV SDN Sentul 3, Kota Blitar dan mendapatkan nilai uji kepraktisan sebesar 100\%. Selain itu, media game edukasi Kirun Mission mendapatkan respon yang baik dari siswa kelas IV SD. Siswa sangat antusias dan merasa tertarik mengikuti kegiatan pembelajaran dengan menggunakan media game edukasi Kirun Mission meskipun pelaksanaannya hanya dilakukan di rumah saja. Hasil penilaian kepraktisan dan kemenarikan oleh siswa terhadap media game edukasi Kirun Mission pada kegiatan uji coba kelompok kecil yaitu sebesar 100\%. Selanjutnya, hasil penilaian kepraktisan dan kemenarikan media game edukasi Kirun Mission pada kegiatan uji coba kelompok besar juga mendapatkan nilai sebesar 99,5\%.

\section{Daftar Rujukan}

Akbar, S. (2013). Instrument Perangkat Pembelajaran. Bandung: PT Rosdakarya.

Arif, M. N. (2016). Pengembangan game edukasi interaktif pada mata pelajaran komposisi foto digital kelas XI di SMK Negeri 1 Surabaya. IT-Edu: Jurnal Information Technology and Education, 1(02).

Arikunto. S. (2010). Prosedur Penelitian Suatu Pendekatan Praktik. Jakarta Rineka Cipta.

Cahyo, R. D., Untari, E., \& Murdiyah, S. (2021). Pengembangan multimedia dengan penguatan karakter rasa ingin tahu pada materi sistem peredaran darah manusia Kelas V SDN Gedog 1 Kota Blitar. Jurnal Pembelajaran, Bimbingan, dan Pengelolaan Pendidikan, 1(4), 289-294.

Chabib, M., Djatmika, E. T., \& Kuswandi, D. (2017). Efektivitas pengembangan media permainan ular tangga sebagai sarana belajar tematik SD. Jurnal Pendidikan: Teori, Penelitian, Dan Pengembangan, 2(7), 910918.

Kristiani, D., \& Bemoe, A. (2016). Ensiklopedia Negeriku Pakaian Adat. Jakarta: Bhuana Ilmu Populer.

Kumalasani, M. P. (2018). Kepraktisan penggunaan multimedia interaktif pada pembelajaran tematik kelas IV SD. Jurnal Bidang Pendidikan Dasar, 2(1A), 1-11.

Mahanani, P. (2013). Pengembangan model pembelajaran Together Win (TW) berdasarkan STAD berorientasi kok-konstruksi untuk pembelajaran karakte. Masters thesis, Universitas Negeri Malang.

Musfiqon. (2012). Pengembangan Media dan Sumber Pembelajaran. Jakarta: PT. Prestasi Pustakaraya.

Putri, A. Y. (2020). Seri Kekayaan Nusantara Rumah Adat. Jakarta: PT Mediantara Semesta. 